\title{
Haploinsufficiency of the autism-associated Shank3 gene leads to deficits in synaptic function, social interaction, and social communication
}

Ozlem Bozdagi ${ }^{1,2+}$, Takeshi Sakurai ${ }^{1,2+}$, Danae Papapetrou ${ }^{3}$, Xiaobin Wang ${ }^{4}$, Dara L Dickstein ${ }^{3}$, Nagahide Takahashi², Yuji Kajiwara ${ }^{2}$, Mu Yang ${ }^{6}$, Adam M Katz ${ }^{6}$, Maria Luisa Scattoni ${ }^{6,7}$, Mark J Harris ${ }^{6}$, Roheeni Saxena ${ }^{6}$, Jill L Silverman ${ }^{6}$, Jacqueline N Crawley ${ }^{6}$, Qiang Zhou ${ }^{4,8}$, Patrick R Hof ${ }^{3}$, Joseph D Buxbaum ${ }^{1,2,3,5^{*}}$

\begin{abstract}
Background: SHANK3 is a protein in the core of the postsynaptic density (PSD) and has a critical role in recruiting many key functional elements to the PSD and to the synapse, including components of $\alpha$-amino-3-hydroxyl-5methyl-4-isoxazole-propionic acid (AMPA), metabotropic glutamate (mGlu) and N-methyl-D-aspartic acid (NMDA) glutamate receptors, as well as cytoskeletal elements. Loss of a functional copy of the SHANK3 gene leads to the neurobehavioral manifestations of $22 q 13$ deletion syndrome and/or to autism spectrum disorders. The goal of this study was to examine the effects of haploinsufficiency of full-length Shank3 in mice, focusing on synaptic development, transmission and plasticity, as well as on social behaviors, as a model for understanding SHANK3 haploinsufficiency in humans.
\end{abstract}

Methods: We used mice with a targeted disruption of Shank3 in which exons coding for the ankyrin repeat domain were deleted and expression of full-length Shank3 was disrupted. We studied synaptic transmission and plasticity by multiple methods, including patch-clamp whole cell recording, two-photon time-lapse imaging and extracellular recordings of field excitatory postsynaptic potentials. We also studied the density of GluR1immunoreactive puncta in the CA1 stratum radiatum and carried out assessments of social behaviors.

Results: In Shank3 heterozygous mice, there was reduced amplitude of miniature excitatory postsynaptic currents from hippocampal CA1 pyramidal neurons and the input-output $(I / O)$ relationship at Schaffer collateral-CA1 synapses in acute hippocampal slices was significantly depressed; both of these findings indicate a reduction in basal neurotransmission. Studies with specific inhibitors demonstrated that the decrease in basal transmission reflected reduced AMPA receptor-mediated transmission. This was further supported by the observation of reduced numbers of GluR1-immunoreactive puncta in the stratum radiatum. Long-term potentiation (LTP), induced either with $\theta$-burst pairing (TBP) or high-frequency stimulation, was impaired in Shank3 heterozygous mice, with no significant change in long-term depression (LTD). In concordance with the LTP results, persistent expansion of spines was observed in control mice after TBP-induced LTP; however, only transient spine expansion was observed in Shank3 heterozygous mice. Male Shank3 heterozygotes displayed less social sniffing and emitted fewer ultrasonic vocalizations during interactions with estrus female mice, as compared to wild-type littermate controls.

Conclusions: We documented specific deficits in synaptic function and plasticity, along with reduced reciprocal social interactions in Shank3 heterozygous mice. Our results are consistent with altered synaptic development and

\footnotetext{
* Correspondence: joseph.buxbaum@mssm.edu

+ Contributed equally

'Seaver Autism Center for Research and Treatment, Mount Sinai School of

Medicine, New York, NY 10029, USA

Full list of author information is available at the end of the article
}

\section{Biomed Central}

(C) 2010 Bozdagi et al; licensee BioMed Central Ltd. This is an Open Access article distributed under the terms of the Creative Commons Attribution License (http://creativecommons.org/licenses/by/2.0), which permits unrestricted use, distribution, and reproduction in any medium, provided the original work is properly cited. 
function in Shank3 haploinsufficiency, highlighting the importance of Shank3 in synaptic function and supporting a link between deficits in synapse function and neurodevelopmental disorders. The reduced glutamatergic transmission that we observed in the Shank3 heterozygous mice represents an interesting therapeutic target in Shank3-haploinsufficiency syndromes.

\section{Background}

\section{The Shank protein family}

Shank proteins, which include Shanks 1, 2 and 3, were first identified in a yeast two-hybrid assay using the guanylate kinase-associated protein (GKAP, also called SAPAP1, DLGAP1 and DAP-1) as bait [1]. GKAP is a PSD-95-binding protein that forms an important component of the postsynaptic density (PSD), where proteinprotein interactions between scaffolding proteins and receptors are a key mechanism in assembling a functional synapse [2]. Shanks are highly enriched in the PSD and contain five domains for protein-protein interactions, including an ankyrin repeat domain, an Src homology 3 (SH3) domain, a PSD-95/discs large/zonula occludens-1 (PDZ) domain, several proline-rich regions and a C-terminal sterile $\alpha$-motif (SAM) domain [3] (Figure 1). The PDZ domain mediates the interaction of Shanks with the $\mathrm{COOH}$ terminus of several different proteins, including GKAP $[1,4]$, G protein-coupled receptors $[5,6]$ and the $\mathrm{COOH}$ terminus of group I metabotropic glutamate receptors (mGluRs) [7]. GKAP mediates the binding of Shanks to $N$-methyl-D-aspartic acid (NMDA) and $\alpha$-amino-3-hydroxyl-5-methyl-4-isoxazole-propionic acid (AMPA) receptors [8]. In addition, the SAM domain interacts with GKAP [7], while proline-rich regions of the Shank proteins bind the mGluR-binding protein Homer [7], actin-binding protein Abp-1 $[9,10]$ and cortactin (cortical actin-binding protein) [11], which promotes polymerization of the actin cytoskeleton, an important modulator of long-term synaptic plasticity [12]. Shanks interact directly with AMPA receptors through the SH3 domain [13]. Interaction of the ankyrin repeats of Shanks with $\alpha$-fodrin may mediate calmodulin-mediated processes after synaptic stimulation through interactions with actin and calmodulin [14]. Sharpin can also interact with the Shanks [15] and may be involved in activity-dependent modification in dendritic spines.

\section{Shank proteins in synaptic biology}

There are $~ 300$ individual Shank molecules in a single postsynaptic site, representing $\sim 5 \%$ of the total protein molecules and total protein mass in the site [16]. It would therefore not be surprising that alteration in Shank expression could profoundly affect synaptic morphology and function. Such a crucial role for Shank levels in synaptic function is supported by the observation that overexpression of Shank1 led to increased spine size in neurons in culture [17]. Additional studies showed that knockout of Shank1 leads to a decrease in spine number and spine and PSD size, decreased levels of GKAP and Homer, and reduced basal synaptic transmission [18]. Furthermore, inhibition of Shank3 expression has been shown to reduce numbers of spines in hippocampal neurons in culture and, conversely, when Shank3 was introduced into aspiny cerebellar neurons in vitro, the neurons developed spines with functional glutamatergic synapses expressing NMDA, AMPA and mGlu receptors [19].

\section{Haploinsufficiency of SHANK3 in neurodevelopmental syndromes}

Chromosome 22q13 deletion syndrome (22q13DS, also called Phelan-McDermid syndrome) was first described in the early 1990s (reviewed in [20]). Affected individuals show global developmental delays with absent or severely delayed expressive speech, and they may have autism spectrum disorders (ASDs). Careful analysis of the extent of the deletion in dozens of independent cases indicated the presence of a small "critical region" encompassing SHANK3 [21,22], providing the first line of evidence that a dysfunction in SHANK3 may be responsible for the neurobehavioral aspects of 22q13DS. The second line of evidence was the demonstration of a recurrent breakpoint in SHANK3 in some cases with 22q13DS [23,24], which led these authors to conclude that disruption of this single gene might be sufficient to cause 22q13DS. Third, there are translocations in SHANK3 that lead to 22q13DS [25]. Finally, several recent studies demonstrated that even de novo point mutations in SHANK3 can produce the entirety of neurodevelopmental symptoms of 22q13DS, including global developmental delay, absent or severely delayed expressive speech, and ASDs [26-28]. Neurobehavioral phenotypes associated with mutation or deletion of SHANK3 are here referred to as SHANK3-haploinsufficiency syndromes and, as noted above, can be associated with ASDs. Interestingly, overexpression of SHANK3 may also result in an ASD as evidenced by reports of Asperger syndrome in an individual with three copies of the SHANK3 locus [27]. Recently, de novo missense and nonsense mutations in SHANK3 have been described in atypical schizophrenia (with mild to moderate intellectual disability, early onset and dysmorphic features [29]). Mutations in the highly related gene SHANK2 have also 


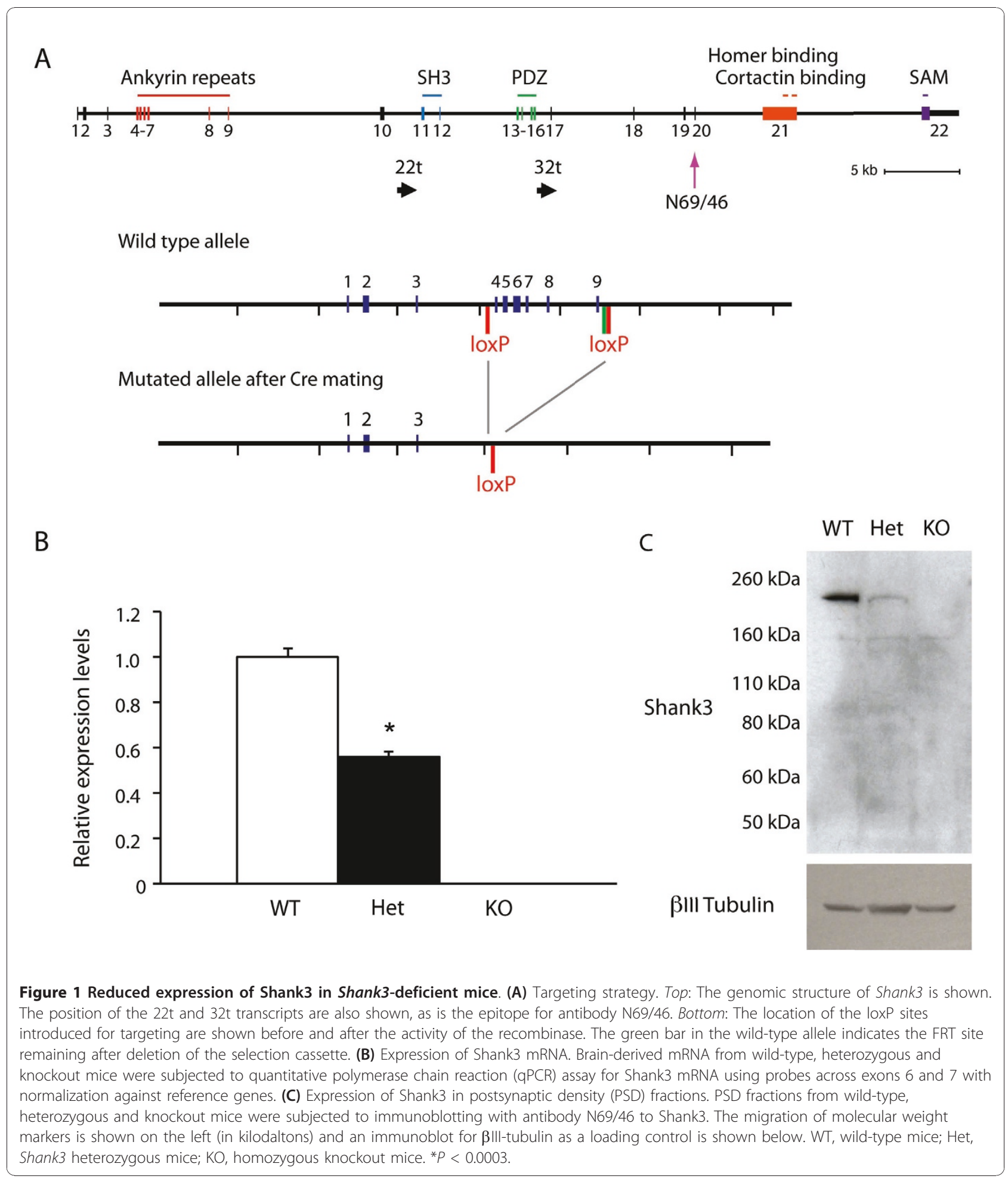

recently been associated with ASDs and/or intellectual disability [29-31].

In the current study, we characterized mice with a targeted disruption of Shank3 as a model for SHANK3haploinsufficiency syndromes. We focused on synaptic biology and synaptic function as the most proximal target for altered Shank3 expression. We also examined social interaction and social communication in Shank3 heterozygotes and their wild-type littermates. The results are consistent with an important role for 
SHANK3 in synaptic function and plasticity and implicate specific pathways as potential therapeutic targets for SHANK3-haploinsufficiency syndromes.

\section{Methods}

Generation of mice with a disruption of the Shank3 gene Animal procedures were approved by the Mount Sinai School of Medicine and the National Institute of Mental Health Animal Care and Use committees. We made use of gene targeting in Bruce4 C57BL/6 embryonic stem (ES) cells [32] to generate a mouse line that has loxP sites inserted before exon 4 and after exon 9 (encoding the ankyrin repeats), with the selection cassette (flanked by FRT sites) excised by FLP recombinase. This floxed strategy was chosen to allow us the option of doing conditional (region-specific) knockouts if needed. C57BL/6 was used as the chosen embryonic stem cell line because of the more robust social and cognitive abilities in this line as compared to many of the 129-derived ES lines. For all studies reported here, the floxed allele was first excised by crossing with a CMV-Cre transgenic line (again on a C57BL/6 background) that has ubiquitous Cre expression and a line maintained with a deletion of exons 4 through 9. This Shank3-deficient line was carried forward by crossing heterozygotes with the C57BL/ 6 strain to maintain a pure C57 background suitable for electrophysiology and behavioral analyses.

\section{Quantitative polymerase chain reaction}

RNA was extracted from brain cortex using the RNeasy Mini Kit (Qiagen, Valencia, CA, USA) according to the manufacturer's instructions. cDNA was synthesized with the High Capacity cDNA Reverse Transcription Kit (Applied Biosystems, Carlsbad, CA, USA). The universal probe library (UPL) system (Roche, Indianapolis, IN, USA) was used to perform quantitative polymerase chain reaction (qPCR). Primers located in exons 6 and 7 of Shank3 (NM_021423) were designed using ProbeFinder Software (Roche). Three reference genes (Actb, Gapd and $R p l 13 a$ ) were used for normalization, and relative expression levels were calculated using qBase software [33], now available from Biogazelle (Ghent, Belgium). Primer sequences and UPL probe numbers were Shank3, forward tggttggcaagagatccat, reverse ttggccccatagaacaaaag, \#1; Actb, forward ggatgcagaaggagattactgc, reverse ccaccgatccacacagagta, \#63; Gapd, Fw gccaaaagggtcatcatctc, reverse cacacccatcacaaacatgg, \#29; Rpl 13a, forward tccctgctgctctcaagg, reverse gccccaggtaagcaaactt, \#41. Unpaired $t$-tests were used for group comparisons.

\section{Immunoblotting}

PSD fractions were prepared as follows. Hemibrains of wild-type, heterozygous and homozygous Shank3 mice were homogenized in 2-[4-(2-hydroxyethyl)piperazin-1- yl]ethanesulfonic acid (HEPES)-A containing $4 \mathrm{mM}$ HEPES, pH 7.4, $0.32 \mathrm{M}$ sucrose, Protease Inhibitor Cocktail and PhoSTOP Phosphatase Inhibitor Cocktail (both from Roche). Nuclear fractions were precipitated by centrifuging twice at $700 \mathrm{~g}$ for $15 \mathrm{~min}$, and the resulting supernatants were further centrifuged at 21,000 $\mathrm{g}$ for $15 \mathrm{~min}$. The precipitates were resuspended in HEPES-B containing $4 \mathrm{mM}$ HEPES, $\mathrm{pH}$ 7.4, Protease Inhibitor Cocktail and PhoSTOP Phosphatase Inhibitor Cocktail, homogenized and rotated at $4^{\circ} \mathrm{C}$ for 1 hour. The lysates were centrifuged at 32,000 $\mathrm{g}$ for $20 \mathrm{~min}$ and washed twice with HEPES-C containing $50 \mathrm{mM}$ HEPES, pH 7.4, 0.5\% Triton X-100, Protease Inhibitor Cocktail and PhoSTOP Phosphatase Inhibitor Cocktail. Finally, postsynaptic density fractions were resuspended in HEPES-C containing $1.8 \%$ sodium dodecyl sulfate (SDS) and 2.5 M urea. Fifty-two $\mu$ g of each PSD fraction were loaded to 4-12\% SDS-polyacrylamide gel electrophoresis (PAGE gel (Invitrogen, Carlsbad, CA, USA), transferred to polyvinylidene fluoride membrane and immunoblotted with either the N69/46 anti-Shank3 antibody directed against an epitope downstream of the PDZ domain (UC Davis/NIH NeuroMab Facility, Davis, CA) or the anti-ProSAP2 anti-Shank3 antibody directed against the last 100 amino acids of Shank3 (Millipore, Billerica, MA, USA). For $\beta$ III tubulin, the membrane was stripped and immunoblotted with an anti- $\beta$ III tubulin antibody (Abcam, Cambridge, MA, USA).

\section{Hippocampal slice electrophysiology \\ Whole cell recording, two-photon time-lapse imaging and analysis}

Methods of recording, imaging and analysis were carried out according to our previously published protocols $[34,35]$. All experiments were conducted on CA1 pyramidal cells at $32^{\circ} \mathrm{C}$ in acute slices taken from Shank3 heterozygous mice and wild-type littermates. Spines were visualized using calcein contained in the patch pipette, making use of a two-photon laser scanning system modified from Olympus Fluoview FV 300 driven by a Chameleon two-photon laser (Coherent, Santa Clara, CA, USA). Baseline synaptic responses were evoked using a glass pipette positioned $\sim 20 \mu \mathrm{m}$ away from the imaged spines and recorded at the soma. Long-term potentiation (LTP) was induced with a $\theta$-burst pairing (TBP) protocol in which two trains of $\theta$-burst stimuli (each train, separated by $20 \mathrm{~s}$, consisted of five bursts at $5 \mathrm{~Hz}$, and each burst contained five pulses at $100 \mathrm{~Hz}$ ) were paired with brief, small postsynaptic depolarization. Volume analysis of individual spines was performed as detailed previously [34]. Briefly, the integrated fluorescence intensity inside a spine head was measured for individual spines at different time points and normalized to the fluorescence intensity of the dendrites from the same image stack to correct for potential changes 
in excitation [36]. Spine volume in the $\theta$-burst stimulation (TBS) experiments was also calculated using the Rayburst algorithm in NeuronStudio software (available from the Computational Neurobiology and Imaging Center, Mount Sinai School of Medicine, New York, NY, USA) following deconvolution of the data [37-39], and we obtained similar results using either approach.

\section{Extracellular recordings}

Hippocampal slices (350 $\mu \mathrm{m}$ thick) were prepared from 4- to 6-week-old heterozygous mice and their wild-type littermate controls. Slices were perfused with Ringer's solution containing (in $\mathrm{mM}$ ): $\mathrm{NaCl}, 125.0 ; \mathrm{KCl}, 2.5$; $\mathrm{MgSO}_{4}, 1.3 ; \mathrm{NaH}_{2} \mathrm{PO}_{4}, 1.0 ; \mathrm{NaHCO}_{3}, 26.2 ; \mathrm{CaCl}_{2}, 2.5$; and glucose, 11.0. The Ringer's solution was bubbled with $95 \%$ $\mathrm{O}_{2}$ and $5 \% \mathrm{CO}_{2}$ at $32^{\circ} \mathrm{C}$ during extracellular recordings (electrode solution: $3 \mathrm{M} \mathrm{NaCl}$ ). Slices were maintained for 1 hour prior to establishment of a baseline of field excitatory postsynaptic potentials (fEPSPs) recorded from stratum radiatum in area CA1, evoked by stimulation of the Schaffer collateral-commissural afferents $(100-\mu$ s pulses every $30 \mathrm{~s}$ ) with bipolar tungsten electrodes placed into area CA3 [40]. Test stimulus intensity was adjusted to obtain fEPSPs with amplitudes that were one-half of the maximal response. The EPSP initial slope $(\mathrm{mV} / \mathrm{ms})$ was determined from the average waveform of four consecutive responses. Input-output $(\mathrm{I} / \mathrm{O})$ curves were generated by plotting the fEPSP slope versus fiber volley amplitude in low- $\mathrm{Mg}^{2+}(0.1 \mathrm{mM})$ solution. AMPA receptor-mediated and NMDA receptor-mediated $\mathrm{I} / \mathrm{O}$ relationships were measured in the presence of 2-amino-5-phosphonopentanoic acid (APV; $50 \mu \mathrm{M})$ and 6-cyano-7-nitroquinoxaline2,3-dione (CNQX; $100 \mu \mathrm{M}$ ), respectively (Sigma, St. Louis, MO, USA).

Paired-pulse responses were measured with an interstimulus interval (ISI) of $50 \mathrm{~ms}$ and are expressed as the ratio of the average responses to the second stimulation pulse (FP2) to the first stimulation pulse (FP1). LTP was induced by either a high-frequency stimulus (four trains of $100-\mathrm{Hz}, 1$-s stimulations separated by $5 \mathrm{~min}$ ) or TBS (15 bursts of four pulses at $100 \mathrm{~Hz}$ separated by 200 $\mathrm{ms}$ ). To induce long-term depression (LTD), Schaffer collaterals were stimulated by low-frequency stimulation (LFS; 900 pulses at $1 \mathrm{~Hz}, 15 \mathrm{~min}$ ) or by a paired-pulse low-frequency stimulation (PP-LFS; $1 \mathrm{~Hz}$ for $20 \mathrm{~min}$, 50-ms interstimulus interval [41]) to induce mGlu receptor-dependent LTD. Data were expressed as means $\pm \mathrm{SD}$, and statistical analyses were performed using analysis of variance (ANOVA) or Student's $t$-test, with significance set at an $\alpha$ level of 0.05 .

\section{Measurement of GluR1-immunoreactive puncta Immunohistochemistry}

Three-month-old animals were anesthetized with $250 \mu \mathrm{l}$ of $15 \%$ chloral hydrate and perfused transcardially with
1\% paraformaldehyde for $1 \mathrm{~min}$ followed by $4 \%$ paraformaldehyde for a total of $13 \mathrm{~min}$. The brains were then removed, hemisected, cut in 50- $\mu$ m-thick sections using a Leica VT1000S Vibratome (Vibratome, Bannockburn, IL, USA) and subsequently stored in phosphate-buffered saline (PBS) until use. Sections were incubated at $37^{\circ} \mathrm{C}$ for $5 \mathrm{~min}$, followed by incubation in acidified pepsin ( $1 \mathrm{ml}$ in a $0.2 \mathrm{~N} \mathrm{HCl}$ solution) for $6.5 \mathrm{~min}$. The tissue was then washed at room temperature in PBS-B $(3 \times 20$ min) and incubated in a $0.3 \%$ Triton $\mathrm{X}-100,0.5 \%$ bovine serum albumin (BSA), 5\% normal goat serum for $1 \mathrm{~h}$ on an orbital shaker. The blocking step was followed by overnight incubation in the primary antibody (rabbit polyclonal antiglutamate receptor 1 AB1504; Millipore, Billerica, MA, USA), which was made in blocking solution at the appropriate dilution $(1 \mu \mathrm{g} / \mathrm{ml})$. The tissue sections were then washed in PBS-B $(5 \times 5 \mathrm{~min})$ and incubated in secondary antibody (goat antirabbit Alexa Fluor 488, Invitrogen) in a $2 \% \mathrm{BSA}$ and $0.3 \%$ Triton PBS-B solution at the appropriate dilution (1:400) for $1 \mathrm{~h}$ at room temperature on an orbital shaker. Finally, the tissue was washed in PBS-B $(3 \times 5 \mathrm{~min})$, stained with 4",6"-diamino-2-phenylindole-2 $\mathrm{HCl}$ (DAPI) and mounted on charged Aqua ColorFrost slides using Vectashield mounting medium (Vector Laboratories, Burlingame, CA, USA).

\section{Tissue sampling}

To quantify puncta, we used a systematic random sampling approach whereby a 1:6 series of sections were stained, the stratum radiatum of the CA1 was contoured using SteroInvestigator (MBF Bioscience, Williston, VT, USA) and the sampling sites were determined using an optical fractionator with the size of the grid set at $18 \mu \mathrm{m}^{2}$ (the dimension of the confocal image stacks to be later sampled with a $\times 100$ lens objective), at a digital zoom of 5 on a Zeiss LSM510 META confocal microscope (Zeiss, Oberkochen, Germany). The trace of the contoured area with an optical fractionator sampling grid placed on it was used as a guide to obtain confocal image stacks of the above-mentioned dimensions that were $100 \mu \mathrm{m}$ apart from each other (i.e., the size of the probe).

\section{Confocal imaging and puncta quantification}

The fluorescent puncta were visualized under a $\times 100$ oil immersion objective (1.4 numerical aperture) in a series of Z-stacks using an Argon/2 laser (488 nm wavelength) at $50 \%$ output (tube current of $6.4 \mathrm{~A}$ and maximum power of $30 \mathrm{~mW}$ ), with a collection band pass spectrum of 505-550 nm (with the following laser and microscope settings: image frame size of $512 \times 512,1$ Airy unit, refractive index correction of 0.9144 and $\mathrm{Z}$ stack interval of $0.1 \mu \mathrm{m}(x, y$ pixel size $=0.05 \mu \mathrm{m}))$ and their intensity, number and size quantified. These settings were optimized during pilot studies and held constant throughout the study. 
The resultant stacks were then deconvolved using AutoDeblur 1.4.1 (Media Cybernetics, Bethesda, MD, USA), using an adaptive point-spread function (PSF) deconvolution method with a theoretical PSF, and then analyzed with custom Vamp2D software [42] that reliably calculates the size of individual puncta on the basis of three-dimensional estimates and circumvents the problem of object superimposition found with more traditional methods that collapse the stacks into twodimensional projections. The relative density of puncta was then calculated per cubic micrometer, and the differences between groups were assessed using the nonparametric Mann-Whitney $U$ test.

\section{Behavioral analyses}

Shank3 wild-type and heterozygote breeding pairs were imported from Mount Sinai School of Medicine to the National Institute of Mental Health. Mice were maintained by breeding C57BL/6 wild-type mice with Shank3 heterozygotes and housed in a conventional temperature- and humidity-controlled vivarium. Littermates were housed by sex in mixed genotype groups of two to four per cage on a 12:12-h circadian cycle with lights on at 0600. Behavioral experiments were conducted between 1000 and 1600 in dedicated testing rooms.

Developmental milestones were tested across postnatal days 2-14, including measures of body weight, body length, tail length, pinnea detachment, eye opening, incisor eruption, fur development, righting reflex, negative geotaxis, cliff avoidance, grasping reflex, auditory startle, bar holding, level screen and vertical screen as previously described $[43,44]$. In addition, the mice were evaluated in a standard, automated three-chambered social approach task as previously described [44].

Male-female social interactions were evaluated in a 5 -min test session as previously described $[43,45]$, with the exception that subject males were group-housed and individually tested in clean cages with clean litter. Each of the 12 wild-type and 14 heterozygous male subject mice, ages 2.5-4 months, was paired with a different unfamiliar estrus C57BL/6J female. A digital closedcircuit television camera (Panasonic, Secaucus, NJ, USA) was positioned horizontally $30 \mathrm{~cm}$ from the cage. An ultrasonic microphone (Avisoft UltraSoundGate condenser microphone capsule CM15; Avisoft Bioacoustics, Berlin, Germany) was mounted $20 \mathrm{~cm}$ above the cage. Sampling frequency for the microphone was $250 \mathrm{kHz}$, and the resolution was 16 bits. The entire apparatus was contained in a sound-attenuating environmental chamber (ENV-018V; Med Associates, St. Albans, VT, USA) illuminated by a single 25 -Watt red light. Videos from the male subjects were subsequently scored by an investigator uninformed of the subject's genotype on measures of nose-to-nose sniffing, nose-to-anogenital sniffing and sniffing of other body regions, using Noldus Observer software (Noldus Information Technology, Leesburg, VA, USA) as previously described. Ultrasonic vocalizations were played back and spectrograms were displayed using Avisoft software [43,45]. Ultrasonic vocalizations were identified manually by two highly trained investigators blinded to genotype information, and summary statistics were calculated using the Avisoft package. Interrater reliability was $95 \%$. Data were analyzed using an unpaired Student's $t$-test.

Olfactory habituation/dishabituation testing was conducted in male and female Shank3 wild-type and heterozygous mice ages 2.5-4 months using methods previously described $[44,46,47]$. Nonsocial and social odors were presented on a series of cotton swabs inserted into the home cage sequentially, each for $2 \mathrm{~min}$, in the following order: water, water, water (distilled water); almond, almond, almond (1:100 dilution almond extract); banana, banana, banana (1:100 dilution artificial banana flavoring); social 1 , social 1 , social 1 (swiped from the bottom of a cage housing unfamiliar sex-matched B6 mice); and social 2, social 2, social 2 (swiped from the bottom of a second cage housing a different group of unfamiliar sex-matched 129/SvImJ mice). One-way repeated measures ANOVA was performed within each genotype for each set of habituation events and each dishabituation event, followed by a Tukey post hoc test.

\section{Results}

\section{Generation and characterization of a Shank3-deficient mouse}

We made use of gene targeting in Bruce4 C57BL/6 embryonic stem (ES) cells [32] to generate a mouse line that has loxP sites inserted before exon 4 and after exon 9 (Figure 1A). For all studies reported here, the floxed allele was excised and a line was maintained with a deletion of exons 4 through 9 . This line, which completely deletes the ankyrin repeat domains of Shank3, produced wild-type $(+/+)$, heterozygous $(+/-)$ and knockout (-/-) animals with Mendelian frequencies from heterozygoteheterozygote crosses.

qPCR showed 50\% reduction of full-length Shank3 mRNA in the heterozygotes and complete loss in knockouts (Figure 1B). Moreover, there was no expression of full-length Shank3 protein in PSD fractions from Shank3-knockout mice and reduced expression in the heterozygotes, using antibodies which cross-react either with an epitope downstream of the PDZ domain (antibody N69/46; see Figure 1A) (Figure 1C) or with the $\mathrm{COOH}$ terminal (data not shown), consistent with haploinsufficiency.

Heterozygous and homozygous animals were viable and showed no obvious alterations in gross brain 
structure or hippocampal cytoarchitecture, nor were there any obvious seizures. There was evidence for subtle motor abnormalities in homozygotes, which is being further characterized in ongoing studies. Both genotypes were normal on measures of general health, developmental milestones and exploratory activity, as well as on social approach as measured in an automated three-chambered social approach task.

Because SHANK3 haploinsufficiency is responsible for the neurobehavioral phenotype in individuals with 22q13DS or SHANK3 mutations, we focused the studies reported here on Shank3 heterozygous mice generated by crossing wild-type mice with heterozygotes to be most relevant to the clinical syndromes and to be most useful in ultimately assessing potential therapeutic interventions in preclinical studies. A comprehensive investigation of the knockout mice obtained through an alternate breeding strategy (heterozygote-heterozygote matings) is now in progress in independent experiments.

\section{Basal glutamatergic synaptic transmission is reduced in Shank3 heterozygous mice}

To examine the role of Shank3 in regulating synaptic glutamate receptor function, we studied glutamatergic synaptic transmission in hippocampal slices. We examined the properties of basic transmission at Schaffer collateral-CA1 synapses in hippocampal slices from 3- to 4-week-old Shank3 heterozygous mice and their littermates using extracellular recordings. Plotting field excitatory postsynaptic potential (fEPSP) slope versus stimulus intensity demonstrated a reduction in the $\mathrm{I} / \mathrm{O}$ curves in the heterozygotes (data not shown), prompting us to then further examine synaptic transmission in the presence of inhibitors of specific subtypes of glutamate receptors. In the presence of the NMDA receptor antagonist APV, a decrease in AMPA receptor-mediated field potentials in the heterozygous mice was seen, reflected as a $50 \%$ decrease in the average slope of $\mathrm{I} / \mathrm{O}$ function compared with wild-type mice $(n=4$ mice per genotype, two to three slices per mouse; $P=0.001$; Figure $2 \mathrm{~A}$ ). In contrast, when the $\mathrm{I} / \mathrm{O}$ relationship was analyzed in the presence of the competitive AMPA/kainate receptor antagonist $C N Q X$ to measure synaptic NMDA receptor function, there was no difference between genotypes ( $n=4$ mice per genotype, two to three slices per mouse; $P=0.1$; Figure $2 \mathrm{~B}$ ). These results indicate that there is a specific reduction in AMPA receptor-mediated basal transmission in the Shank3 heterozygous mice.

We asked whether the impairment of evoked synaptic transmission in heterozygous mice is caused by alterations in presynaptic and/or postsynaptic parameters. We performed whole cell patch-clamp recordings in 3-month-old littermates and monitored spontaneous miniature postsynaptic currents in the presence of tetrodotoxin (TTX). The amplitude of miniature excitatory postsynaptic currents (mEPSCs) from hippocampal CA1 pyramidal neurons of heterozygous mice were significantly smaller than those in control mice $(n=7$ for wild-type and $n=8$ for heterozygous mice, $P<0.01$; Figures $2 \mathrm{C}$ and $2 \mathrm{D}$ ), which was evident by the significant shift of the cumulative probability to the left (Figure 2E), again indicating a reduction in basal transmission. However, in heterozygous mice, the frequency of miniature excitatory postsynaptic currents was significantly higher ( $n=7$ for wild-type and $n=8$ for heterozygous mice, $P<0.03$; Figures $2 \mathrm{C}$ and $2 \mathrm{D}$ ) and pairedpulse ratio was decreased ( $n=6$ for wild-type and $n=7$ for heterozygous mice, $P<0.05$; Figure $2 \mathrm{~F}$ ), which revealed an additional, presynaptic alteration in the heterozygotes as well.

\section{Long-term potentiation is impaired in Shank3 heterozygous mice}

We next examined long-term potentiation (LTP) with extracellular fEPSP recordings at Schaffer collateral/CA1 synapses. In the first set of experiments, LTP was induced by tetanic stimulation of the Schaffer collaterals (four trains of $100 \mathrm{~Hz}$ separated by $5 \mathrm{~min}$ ). While initial expression of LTP was identical across the two genotypes, the maintenance of LTP was clearly impaired in the heterozygous mice (average percentage of baseline $120 \mathrm{~min}$ after tetanus: $165.1 \pm 8.8 \%$ in wild-type and $117.1 \pm 9.5 \%$ in heterozygous mice, $P=0.004$; Figure $3 \mathrm{~A}$ ). In an additional set of experiments, we further tested TBS LTP (10 bursts of four pulses at $100 \mathrm{~Hz}$ separated by $200 \mathrm{~ms}$ ), which also showed a significant decrease in the potentiation at 60 min after TBS in heterozygous mice $(156.3 \pm 9.2 \%$ of baseline in wild-type and $126.0 \pm 8.9 \%$ in heterozygous mice, measured $60 \mathrm{~min}$ after TBS, $P=0.007$; Figure $3 \mathrm{~B}$ ).

In contrast to the altered synaptic plasticity observed with LTP, long-term depression (LTD) induced by either low-frequency stimulation (LFS) $(82.6 \pm 1.35 \%$ of baseline in wild-type and $79.9 \pm 2.5 \%$ in heterozygous mice, measured $60 \mathrm{~min}$ after LFS, $P>0.1$; Figure 3G) or paired-pulse LFS (PP-LFS) stimulation $(81.6 \pm 6 \%$ of baseline in wild-type and $82.7 \pm 1.9 \%$ in heterozygous mice, $P>0.1$; Figure $3 \mathrm{H}$ ) was not significantly changed in heterozygotes.

Previous studies have shown that LTP is accompanied by spine enlargement $[35,48]$. Therefore, it was of interest to determine whether the deficits in LTP in the Shank3 heterozygous mice were associated with altered spine remodeling. We first established that spines from wild-type mice were capable of structural modification by simultaneously monitoring spine size and synaptic responses in CA1 neurons before and after TBP [34,35]. We found that TBP produced a rapid and persistent 
A

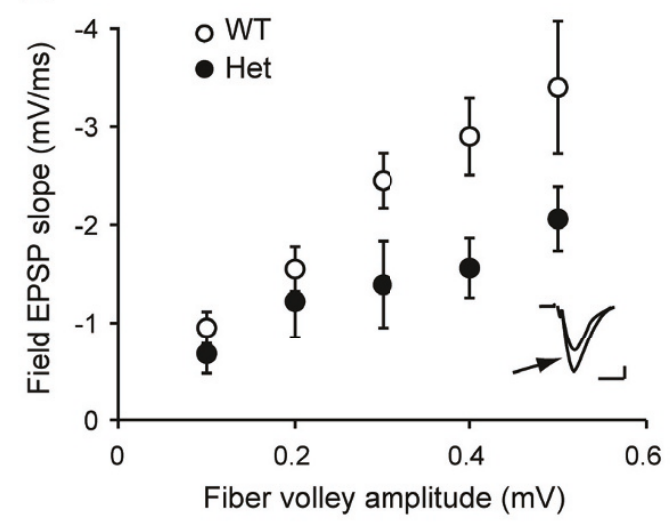

C

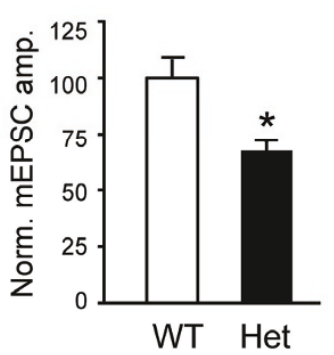

$E$

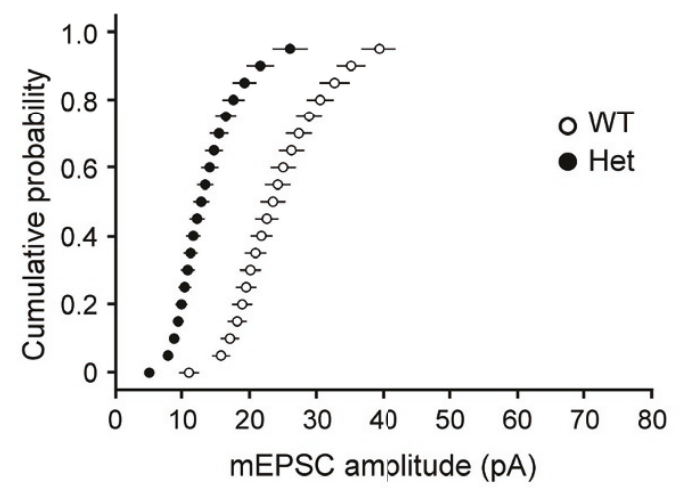

B

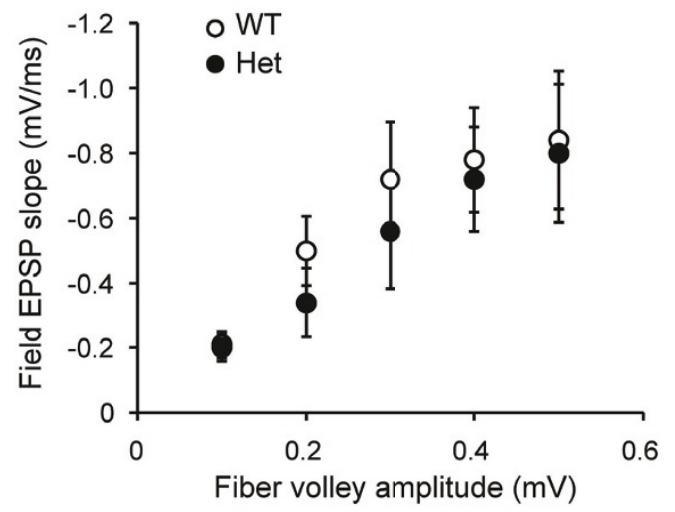

D

WT

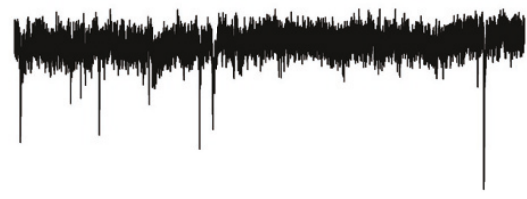

Het

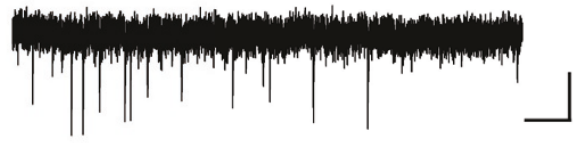

F
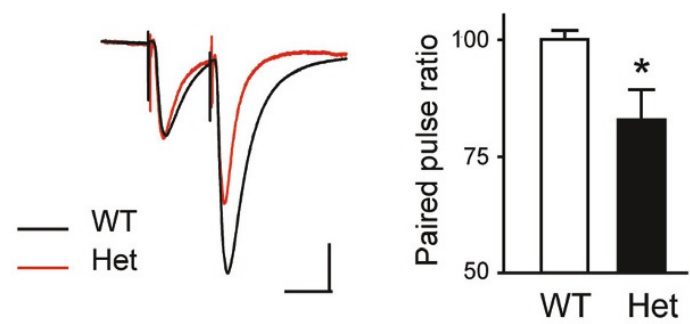

Figure 2 Altered basal synaptic properties in Shank3 heterozygous mice. (A) Reduced $\alpha$-amino-3-hydroxyl-5-methyl-4-isoxazole-propionic acid (AMPA) receptor responses in Shank3 heterozygous mice. Slices were incubated in the presence of 2-amino-5-phosphonopentanoic acid (APV) and mean field excitatory postsynaptic potential (field EPSP) slope as a function of fiber volley is shown for slices derived from wild-type and heterozygous mice. The inset shows representative traces for a given stimulus intensity $(0.5 \mathrm{~mA})$ in the input/output (I/O) graph (arrow indicates the trace from wild-type; scale: $10 \mathrm{~ms}, 0.5 \mathrm{mV}$ ). (B) Normal N-methyl-D-aspartic acid (NMDA) receptor responses in Shank3 heterozygous mice. Slices were incubated in the presence of 6-cyano-7-nitroquinoxaline-2,3-dione (CNQX), and mean field EPSP slope as a function of fiber volley is shown. (C) Miniature excitatory postsynaptic currents (mEPSCs) from wild-type and Shank3 heterozygous mice. Left: Amplitude of mEPSCs. ${ }^{*} P<0.01$. Right: Frequency of mEPSCs. ${ }^{*} P<0.03$. (D) Sample traces of mEPSCs. Scale: $1 \mathrm{~s}, 40$ pA. (E) Cumulative probability of mEPSC amplitude. (F) Paired-pulse ratio. Left: Representative EPSC traces from Shank3 heterozygous (red) and wild-type (black) mice, with traces normalized to the first EPSC for comparison. ${ }^{*} P<0.05$. WT, wild-type mice; Het, Shank3 heterozygous mice. 
A

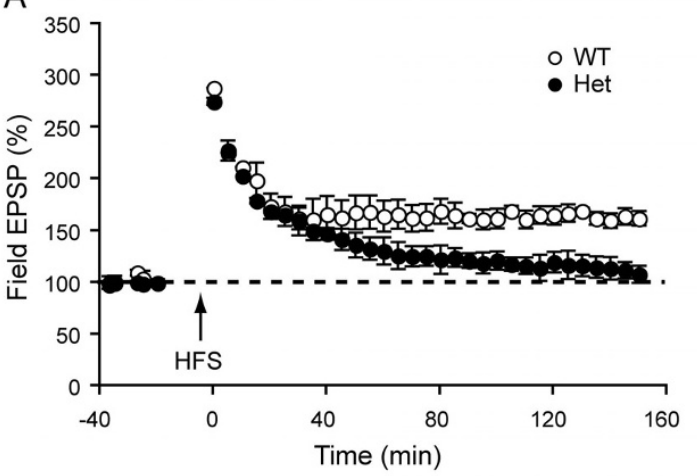

C

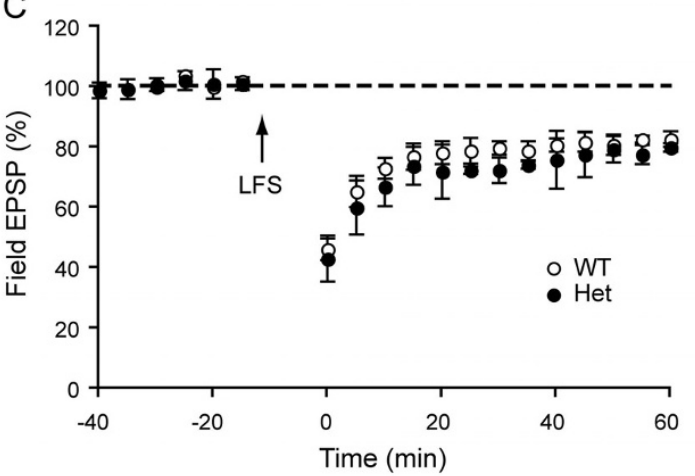

E

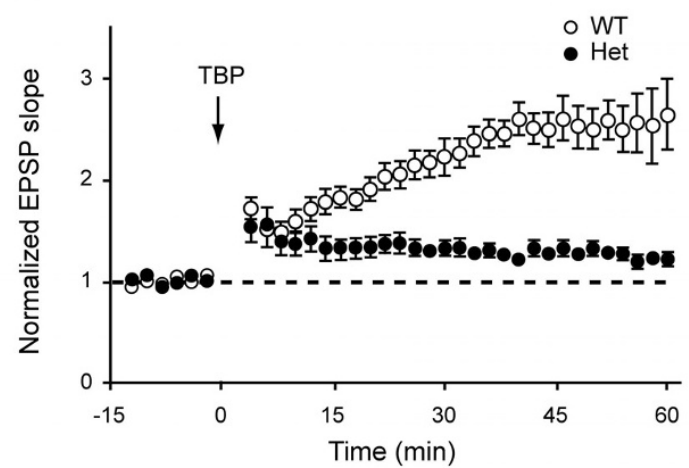

G

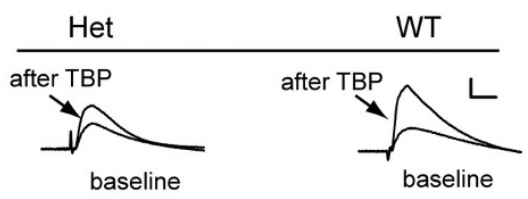

B

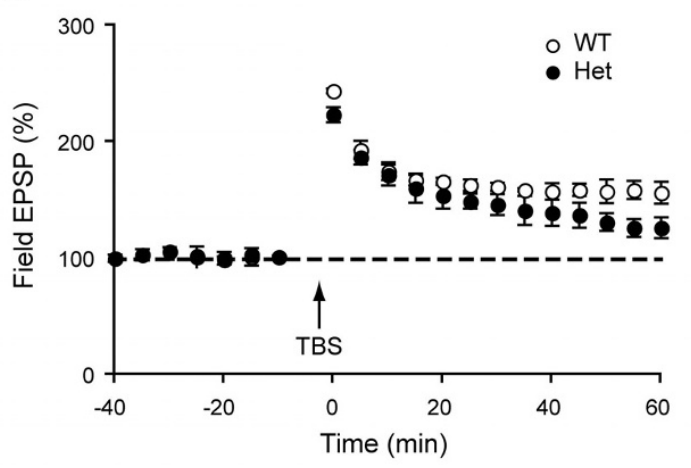

D

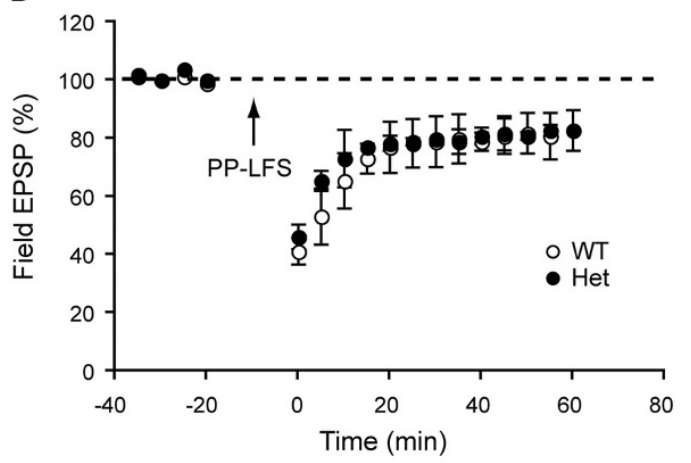

F

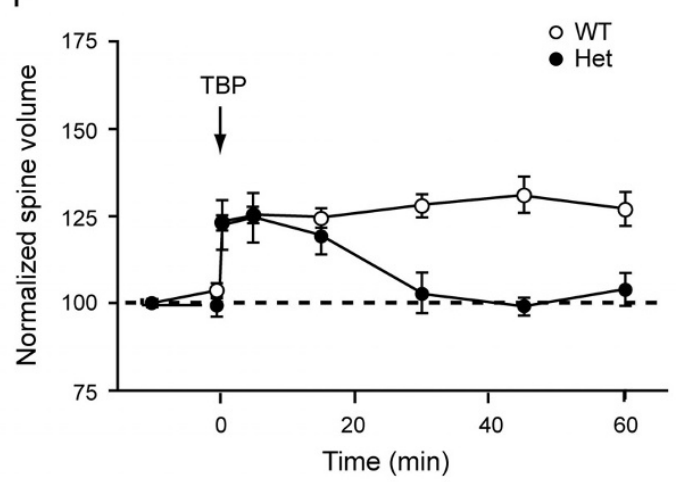

$\mathrm{H}$
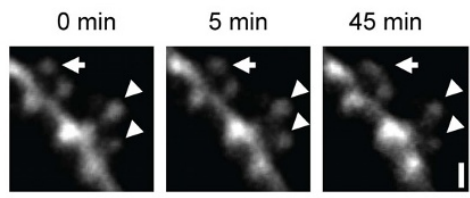

Figure 3 Reduced long-term potentiation in Shank3 heterozygous mice. (A) Long-term potentiation (LTP) following high-frequency stimulation. Field recordings of LTP induced with high-frequency stimulation (HFS; 4 times $100 \mathrm{~Hz}$, separated by 5 min) as a function of time in slices from wild-type and Shank3 heterozygous mice. (B) LTP following $\theta$-burst stimulation (TBS). (C) Long-term depression (LTD) following lowfrequency stimulation (LFS), an NMDA receptor-dependent form of LTD. (D) LTD following paired-pulse low-frequency stimulation (PP-LFS), a protein synthesis-dependent form of LTD. (E) LTP recorded with whole cell patch-clamp method. LTP was induced with $\theta$-burst pairing (TBP). (E) Normalized EPSP slope is shown as a function of time. (G) Representative EPSP traces before and after (arrow) LTP induction (scale bar: 5 mV, 10 ms). (F) Changes in normalized spine volume following LTP. (H) Representative images showing TBP-induced spine expansion in Shank3 heterozygotes. Images were acquired before and $5 \mathrm{~min}$ and $45 \mathrm{~min}$ after TBP. Transiently increased and stable spines are indicated by arrowheads and arrow, respectively (scale bar: $1 \mu \mathrm{m}$ ). WT, wild-type mice; Het, Shank3 heterozygous mice. 
increase in spine volume concurrent with an immediate increase in EPSP slope in whole cell recordings, which gradually reached a plateau by $\sim 30$ min (Figures $3 \mathrm{C}-\mathrm{F}$ ). However, in recordings from heterozygous mice, we found that the stabilization in synaptic potentiation and spine expansion were impaired in CA1 neurons (Figures $3 \mathrm{C}-\mathrm{F})$. In the heterozygous mice, both EPSP slope and spine volume increased immediately to values comparable to those of control spines, but synaptic potentiation and spine expansion failed to be sustained.

\section{GluR1 immunoreactivity is decreased in Shank3 heterozygous mice}

We then asked whether Shank3 haploinsufficiency can lead to alterations in the numbers of AMPA receptorpositive puncta, given the results from the electrophysiological experiments and the relationship between synaptic strength and AMPA receptor subunit trafficking [49]. We carried out immunolabeling for GluR1 (an AMPA receptor subunit) and quantified GluR1-immunoreactive puncta (Figures 4A-G). Neurons from Shank3 heterozygous mice showed significantly fewer GluR1-immunoreactive puncta $(P<0.005)$ consistent with the electrophysiological data.

\section{Behavioral analyses of Shank3 heterozygotes}

To more extensively study social interactions in Shank3 heterozygous mice, we examined male-female social interactions during a 5 -min session of freely moving reciprocal social interactions with an estrus B6 female (Figure 5A). Cumulative duration of total social sniffing by the male test subjects was lower in Shank3 heterozygotes than in wild-type littermates $(P=0.02)$. In addition, fewer ultrasonic vocalizations were emitted by heterozygotes than by wild-type littermates during the male-female social interaction session $(P=0.003)$. Note that while the equipment used could not distinguish between calls emitted by the male subject and female partner, the preponderance of calls during male-female interactions in mice is usually emitted by the male [50].

As a control task to ensure that subject mice can detect the social pheromones that elicit approach and vocalizations, we measured olfactory abilities using the olfactory habituation/dishabituation test. Habituation and dishabituation were normal for social and nonsocial odor cues in both wild-type and Shank3 heterozygous mice ( $n=8$ /genotype; Figure $5 \mathrm{~B}$ ). Both genotypes displayed the expected habituation, indicated by decreased time spent in sniffing the sequence of three same odors, and the expected dishabituation, indicated by increased time sniffing the different odor (water habituation, wildtype: $P<0.001$; water habituation, heterozygotes: $P<$ 0.001 ; almond habituation, wild-type: $P=0.015$; almond habituation, heterozygotes: $P=0.04$; banana habituation, wild-type: $P<0.001$; banana habituation, heterozygotes: $P=0.033$; social odor 1 habituation, wild-type: $P<$ 0.001 ; social odor 1 habituation, heterozygotes: $P<$ 0.001 ; social odor 2 habituation, wild-type: $P<0.001$; social odor 2 habituation, heterozygotes: $P<0.001$; water to almond dishabituation, wild-type: $P=0.061$; water to almond dishabituation, heterozygotes: $P=$ 0.118 ; almond to banana dishabituation, wild-type: $P=$ 0.005; almond to banana dishabituation, heterozygotes: $P=0.046$; banana to social odor 1 dishabituation, wildtype: $P<0.001$; banana to social odor 1 dishabituation, heterozygotes: $P=0.046$; social odor 1 to social odor 2 dishabituation, wild-type: $P<0.001$; social odor 1 to social odor 2 dishabituation, heterozygotes: $P<0.001$ ).

\section{Discussion}

In the present study, we summarize our results in mice with a disruption of the full-length Shank3 protein. We observed reductions in glutamatergic synaptic transmission and plasticity, including deficits in AMPA receptormediated transmission and spine remodeling. We also identified a reduced number of GluR1-immunoreactive puncta in the striatum radiatum. Finally, we saw evidence of social interaction and social communication deficits in these mice. These results demonstrate the importance of Shank3 in synaptic function, ultimately leading to behavioral changes, which may be relevant to the symptoms in individuals with SHANK3 mutations.

\section{Development of the Shank3-deficient model}

Our study targeted the full-length reference Shank3. A recent report has indicated that there are additional start sites in the human and mouse SHANK3 gene that may lead to shorter products, truncated at the $\mathrm{N}$ terminus (termed 22t and 32t in that report [51]). It is therefore possible that our Shank3-deficient mice are still expressing shorter forms of Shank3 protein. We examined the possibility that there were high levels of such shorter forms of Shank3 in mouse brain, making use of an antibody with an epitope downstream of the PDZ domain (antibody N69/46; see Figure 1A) that should recognize both the longer form and the predicted shorter (22t and 32t) forms (if expressed in the same frame as the longer form) (see transcripts labeled $22 \mathrm{t}$ and $32 \mathrm{t}$ in Figure 1A). In PSD fractions (see Figure 1) and in mouse brain extracts [52], we saw strong expression of only a single form and little evidence for high expression of shorter forms. However, the caveat remains that all deficits seen with deletion of the entire SHANK3 gene (including 22t and $32 \mathrm{t}$ forms) may not be fully recapitulated in the model presented here. We do note that a de novo mutation in the ankyrin repeat domain has been reported in a child with an ASD [27], providing strong support for a role for loss of the longer 


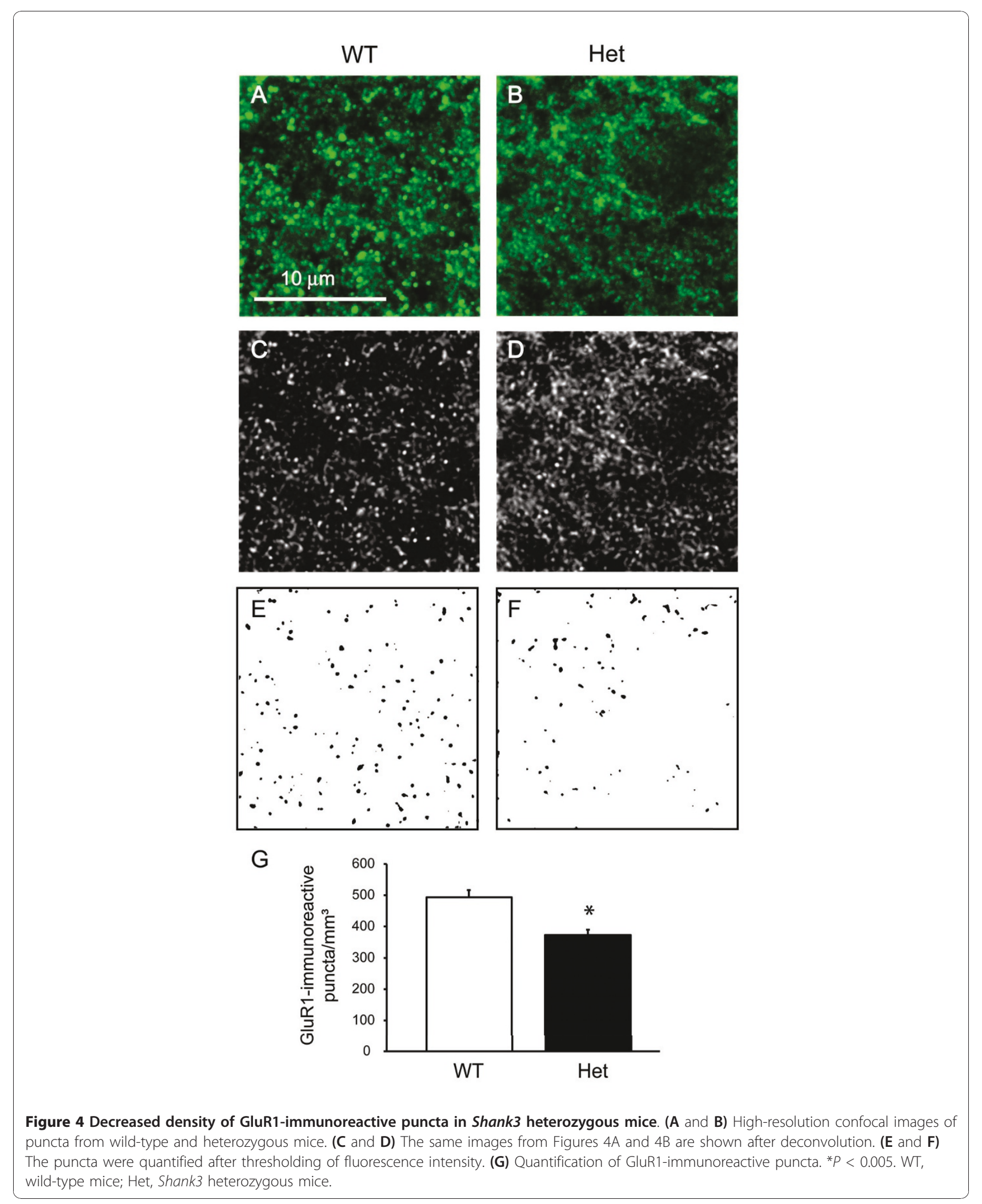



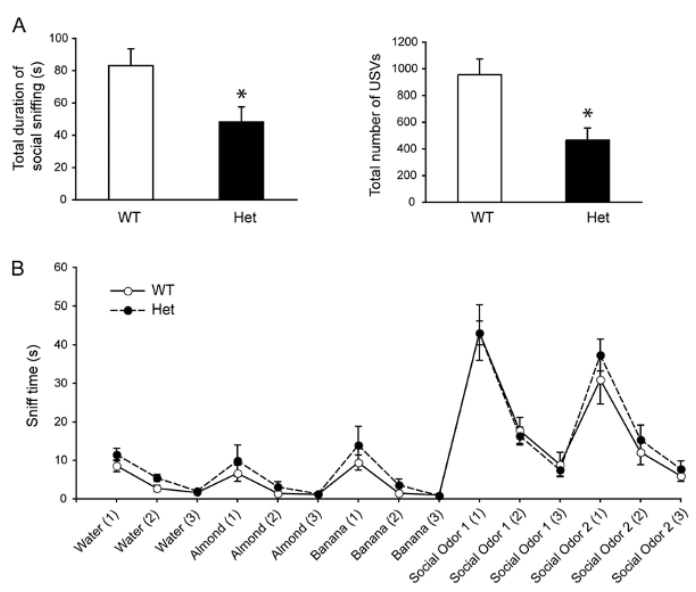

Figure 5 Reduced social behaviors in Shank3 heterozygous and wild-type littermate mice. (A) Adult male-female social interactions. Left: Total duration of social interactions, scored as cumulative seconds spent by the male subject in sniffing the nose, anogenital and other body regions of an unfamiliar adult estrus B6 female mouse during a 5 -min test session in a clean, empty mouse cage. ${ }^{*} P=0.02$. Right: Number of ultrasonic vocalizations emitted during the social interaction test session $\left({ }^{*} P=0.003\right)(n=12$ for wild-type (WT) and $n=14$ for heterozygous (Het) mice). (B) Olfactory habitutation and dishabituation to nonsocial and social odors, measured as cumulative time spent sniffing a sequence of identical and novel odors delivered on cotton swabs inserted into a clean cage ( $n=8$ mice/genotype).

ankyrin repeat domain-containing form in neurodevelopmental disabilities. Hence, disruption of this form, as done in the current study, has direct construct validity to ASD and to neurodevelopmental disabilities. It will be of interest to determine where and to what levels the $22 t$ and 32t forms are expressed and to assess whether neuronal and/or other phenotypes are associated with their disruption. Careful characterization of mice with a disruption of Shank3 by targeting downstream exons common to the full-length, 22t and 32t forms will be of great interest, with the caveat that such targeting may produce dominant-negative shorter products truncated at the $\mathrm{C}$-terminal that, depending on the exons targeted, may or may not be relevant to known clinical mutations.

\section{Synaptic development and function in Shank3 heterozygotes}

Electrophysiological studies of the mice showed a decrease in basal synaptic transmission in heterozygotes when assessed by comparing either the I/O relationship using field recordings or the amplitude of miniature excitatory postsynaptic currents (mEPSCs) using patch clamp recordings. This reduction in AMPA receptordependent transmission is likely mediated by a decrease in the number of synaptic AMPA receptors. Shank3 heterozygous mice also showed a decrease in the density of GluR1-immunoreactive puncta, consistent with a reduction in AMPA receptor levels. On the other hand, both increase in mEPSC frequency and decrease in paired pulse ratio in Shank3 heterozygous mice were consistent with an increase in presynaptic release.

Transfection of Shank3 into aspiny cerebellar granule cells has been shown to induce an increase in the AMPA component of mEPSCs [19], and Shank3 is colocalized with GluR1-containing AMPA receptor in typical spines [53]. In our studies, haploinsufficiency of Shank3 in vivo leads to reduced levels of AMPA receptors and GluR1-positive puncta, results which are consistent with such studies in vitro. However, while the postsynaptic alterations in the Shank3-deficient mice are consistent with studies carried out in vitro, understanding the changes in presynaptic function observed in our analyses will need further investigation. This presynaptic alteration could be explained by compensatory mechanisms in the Shank3 heterozygous mice to maintain constant synaptic function. However, this compensatory effect falls short as evidenced by the reduction in the $\mathrm{I} / \mathrm{O}$ relationship.

Selective acquisition of AMPA receptors is thought to be a crucial mechanism for synapse maturation and function, and our data confirm that Shank3 is an important mediator of AMPA receptor recruitment and of synaptic development.

\section{Synaptic plasticity and spine remodelling in Shank3 heterozygotes}

We examined LTP induced by either high frequency stimulation or TBS. In Shank3 heterozygous mice, reduced LTP was apparent at 30 min after induction in either paradigm and no potentiation was observed at $120 \mathrm{~min}$ after induction. However, the initial expression of LTP was normal with either induction paradigm. We observed similar deficits in the spine expansion that normally accompanies LTP, such that the initial expansion was normal in heterozygotes but quickly decayed to baseline. The simplest explanation for these deficits is an alteration in the trafficking of AMPA receptors to synapses. AMPA receptor trafficking is involved in activity-induced changes in synaptic strength associated with learning and memory [54], and synaptic insertion of GluR1-containing AMPA receptors is required $[55,56]$. The quantity of surface receptors controls synaptic strength [57-59]; therefore, reduction of both synaptic transmission and plasticity in the Shank3 heterozygotes would support a mechanism involving altered AMPA receptor trafficking. Initial LTP is likely mediated by phosphorylation of AMPA receptors, and the initial spine expansion occurs in the absence of trafficking of AMPA receptors [54]. However, AMPA receptor 
trafficking to the synapse is critical to sustain LTP and spine expansion. The transient nature of synaptic potentiation and spine enlargement in heterozygous mice is consistent with normal phosphorylation of existing synaptic AMPA receptors with a deficit in subsequent consolidation, the process in which both structural and functional forms of plasticity are progressively stabilized over $30 \mathrm{~min}$ [34].

\section{Social behavior in Shank3 heterozygotes}

Male Shank3 heterozygous mice displayed reduced responses to female social cues compared to their wildtype littermates on parameters of social sniffing and ultrasonic vocalizations in a male-female reciprocal social interaction context. Given that Shank3 has a central role in synaptic function, Shank3-related changes in cellular and network components that underlie social cognition could underlie the reduced social interactions in Shank3 heterozygous mice. It was interesting that social deficits were not observed in a three-chamber social approach task, implying some specificity of the social alterations. It will be of interest to better understand the frequency of ASD and the characteristics of social deficits in SHANK3-haploinsufficiency syndromes, as it is already evident that this is not a universal finding in these syndromes when considering 22q13DS or schizophrenia.

The social deficits observed in the mice serve as important reminders that systems outside the hippocampus that are involved in social behaviors will need to be examined in these mice and that additional behaviors known to be mediated by the hippocampus will be important for further investigations. Cellular and electrophysiological analyses in additional brain regions and large-scale behavioral studies are now underway for the Shank3-deficient mice in the authors' laboratories.

\section{Conclusions}

Haploinsufficiency of full-length Shank3 resulted in a decrease in synaptic transmission, altered functional and structural plasticity of synapses and reduced social behaviors. These findings are consistent with a model of delayed synaptic development in Shank3 haploinsufficiency, together with a reduction in AMPA receptor trafficking. The results highlight the importance of Shank3 in synaptic development and function and support a link between deficits in synapse function and neurodevelopmental disorders. To date, pharmacological treatments for ASDs and other developmental disorders (including SHANK3-haploinsufficiency syndromes) are primarily ameliorative, focusing on managing associated systems such as anxiety, aggression, repetitive behaviors, attention deficits and epilepsy, among others (see, for example, [60]). Pharmacological treatments addressing core diagnostic symptoms, including, in ASDs, alterations in reciprocal social interactions and communication, do not yet exist. Recently, the field has begun to see the evaluation of therapies targeted to etiology (that is, "personalized medicine") using models of neurodevelopmental disorders including fragile $\mathrm{X}$, tuberous sclerosis, and Rett syndromes (see, for example, [61-64]). The use of model systems such as the Shank3-deficient mice reported here could lead to similar advances in the case of SHANK3-haploinsufficiency syndromes. One interesting outcome of the current study is that compounds that enhance glutamatergic transmission, including those that specifically enhance AMPA transmission (AMPAkines) could possibly represent therapeutic approaches in these conditions. Further analysis of this and additional models may identify targets for novel therapeutics for individuals with developmental delays arising from $22 \mathrm{q} 13$ deletion syndrome or SHANK3 mutations.

\section{Acknowledgements}

This work was supported by the Seaver Foundation, the Simons Foundation, the National Institute of Mental Health Intramural Research Program, and by a gift from Paulina Rychenkova, PhD, and William Gibson. OB and TS are Seaver Junior Faculty Fellows. We thank Lisa Krug and Shekhar Patil for help at early stages of the project.

\section{Author details}

'Seaver Autism Center for Research and Treatment, Mount Sinai School of Medicine, New York, NY 10029, USA. ²Department of Psychiatry, Mount Sinai School of Medicine, New York, NY 10029, USA. ${ }^{3}$ Department of Neuroscience, Mount Sinai School of Medicine, New York, NY 10029, USA. ${ }^{4}$ Department of Neurology, Mount Sinai School of Medicine, New York, NY 10029, USA. ${ }^{5}$ Department of Genetics and Genomic Sciences, Mount Sinai School of Medicine, New York, NY 10029, USA. ' Laboratory of Behavioral Neuroscience, National Institute of Mental Health, Bethesda, MD 20892-3730, USA. ${ }^{7}$ Istituto Superiore di Sanità, Rome, Italy. ${ }^{8}$ Genentech, South San Francisco, CA 94080, USA.

\section{Authors' contributions}

TS and JDB generated and biochemically characterized the mice. JDB, PRH, JNC, TS, QZ and OB designed the experiments. OB, XW and QZ performed the electrophysiology experiments and analysis. Immunohistochemistry as well as confocal microscopy and analysis were conducted by DP, DLD and $\mathrm{PRH}$. Behavioral experiments and analysis were conducted by MY, AMK, MLS, $\mathrm{MJH}, \mathrm{RS}$, JLS and JNC. QPCR was conducted by NT. Immunoblotting was conducted by YK. The manuscript was written by OB and JDB, and all authors reviewed the manuscript before submission.

\section{Competing interests}

$\mathrm{OB}, \mathrm{TS}$ and JDB have submitted a patent on this work.

Received: 14 October 2010 Accepted: 17 December 2010 Published: 17 December 2010

\section{References}

1. Naisbitt S, Kim E, Tu JC, Xiao B, Sala C, Valtschanoff J, Weinberg RJ, Worley PF, Sheng M: Shank, a novel family of postsynaptic density proteins that binds to the NMDA receptor/PSD-95/GKAP complex and cortactin. Neuron 1999, 23:569-582.

2. Sheng M: Excitatory synapses. Glutamate receptors put in their place. Nature 1997, 386:221-223.

3. Sheng M, Kim E: The Shank family of scaffold proteins. J Cell Sci 2000, 113(Pt 11):1851-1856. 
4. Yao I, lida J, Nishimura W, Hata Y: Synaptic localization of SAPAP1, a synaptic membrane-associated protein. Genes Cells 2003, 8:121-129.

5. Zitzer H, Richter D, Kreienkamp HJ: Agonist-dependent interaction of the rat somatostatin receptor subtype 2 with cortactin-binding protein 1. J Biol Chem 1999, 274:18153-18156.

6. Kreienkamp HJ, Soltau M, Richter D, Bockers T: Interaction of G-proteincoupled receptors with synaptic scaffolding proteins. Biochem Soc Trans 2002, 30:464-468.

7. Tu JC, Xiao B, Naisbitt S, Yuan JP, Petralia RS, Brakeman P, Doan A, Aakalu VK, Lanahan AA, Sheng M, Worley PF: Coupling of mGluR/Homer and PSD-95 complexes by the Shank family of postsynaptic density proteins. Neuron 1999, 23:583-592.

8. Kim JH, Kim JH, Yang E, Park JH, Yu YS, Kim KW: Shank 2 expression coincides with neuronal differentiation in the developing retina. Exp Mol Med 2009, 41:236-242.

9. Qualmann B, Boeckers TM, Jeromin M, Gundelfinger ED, Kessels MM: Linkage of the actin cytoskeleton to the postsynaptic density via direct interactions of Abp1 with the ProSAP/Shank family. J Neurosci 2004, 24:2481-2495

10. Haeckel A, Ahuja R, Gundelfinger ED, Qualmann B, Kessels MM: The actinbinding protein Abp1 controls dendritic spine morphology and is important for spine head and synapse formation. J Neurosci 2008, 28:10031-10044

11. Du Y, Weed SA, Xiong WC, Marshall TD, Parsons JT: Identification of a novel cortactin $\mathrm{SH} 3$ domain-binding protein and its localization to growth cones of cultured neurons. Mol Cell Biol 1998, 18:5838-5851.

12. Cingolani LA, Goda Y: Actin in action: the interplay between the actin cytoskeleton and synaptic efficacy. Nat Rev Neurosci 2008, 9:344-356.

13. Sheng M, Kim MJ: Postsynaptic signaling and plasticity mechanisms. Science 2002, 298:776-780.

14. Vanderklish PW, Krushel LA, Holst BH, Gally JA, Crossin KL, Edelman GM: Marking synaptic activity in dendritic spines with a calpain substrate exhibiting fluorescence resonance energy transfer. Proc Natl Acad Sci USA 2000, 97:2253-2258.

15. Lim S, Naisbitt S, Yoon J, Hwang Jl, Suh PG, Sheng M, Kim E: Characterization of the Shank family of synaptic proteins. Multiple genes, alternative splicing, and differential expression in brain and development. J Biol Chem 1999, 274:29510-29518.

16. Sugiyama Y, Kawabata I, Sobue K, Okabe S: Determination of absolute protein numbers in single synapses by a GFP-based calibration technique. Nat Methods 2005, 2:677-684.

17. Sala C, Piech V, Wilson NR, Passafaro M, Liu G, Sheng M: Regulation of dendritic spine morphology and synaptic function by Shank and Homer. Neuron 2001, 31:115-130.

18. Hung AY, Futai K, Sala C, Valtschanoff JG, Ryu J, Woodworth MA, Kidd FL, Sung CC, Miyakawa T, Bear MF, et al: Smaller dendritic spines, weaker synaptic transmission, but enhanced spatial learning in mice lacking Shank1. J Neurosci 2008, 28:1697-1708.

19. Roussignol G, Ango F, Romorini S, Tu JC, Sala C, Worley PF, Bockaert J, Fagni L: Shank expression is sufficient to induce functional dendritic spine synapses in aspiny neurons. J Neurosci 2005, 25:3560-3570.

20. Phelan MC, Rogers RC, Saul RA, Stapleton GA, Sweet K, McDermid H, Shaw SR, Claytor J, Willis J, Kelly DP: 22q13 deletion syndrome. Am J Med Genet 2001, 101:91-99.

21. Luciani JJ, de Mas P, Depetris D, Mignon-Ravix C, Bottani A, Prieur M, Jonveaux P, Philippe A, Bourrouillou G, de Martinville B, et al: Telomeric $22 q 13$ deletions resulting from rings, simple deletions, and translocations: cytogenetic, molecular, and clinical analyses of 32 new observations. J Med Genet 2003, 40:690-696.

22. Wilson HL, Wong AC, Shaw SR, Tse WY, Stapleton GA, Phelan MC, Hu S, Marshall J, McDermid HE: Molecular characterisation of the 22q13 deletion syndrome supports the role of haploinsufficiency of SHANK3/ PROSAP2 in the major neurological symptoms. J Med Genet 2003, 40:575-584.

23. Bonaglia MC, Giorda R, Borgatti R, Felisari G, Gagliardi C, Selicorni A, Zuffardi O: Disruption of the ProSAP2 gene in a $t(12 ; 22)(q 24.1 ; q 13.3)$ is associated with the 22q13.3 deletion syndrome. Am J Hum Genet 2001, 69:261-268.

24. Bonaglia MC, Giorda R, Mani E, Aceti G, Anderlid BM, Baroncini A, Pramparo T, Zuffardi O: Identification of a recurrent breakpoint within the
SHANK3 gene in the 22q13.3 deletion syndrome. J Med Genet 2006 43:822-828.

25. Phelan MC: Deletion 22q13.3 syndrome. Orphanet Journal of Rare Diseases 2008, 3:14.

26. Durand CM, Betancur C, Boeckers TM, Bockmann J, Chaste P, Fauchereau F, Nygren G, Rastam M, Gillberg IC, Anckarsater H, et al: Mutations in the gene encoding the synaptic scaffolding protein SHANK3 are associated with autism spectrum disorders. Nat Genet 2007, 39:25-27.

27. Moessner R, Marshall CR, Sutcliffe JS, Skaug J, Pinto D, Vincent J, Zwaigenbaum L, Fernandez B, Roberts W, Szatmari P, Scherer SW: Contribution of SHANK3 mutations to autism spectrum disorder. Am J Hum Genet 2007, 81:1289-1297.

28. Gauthier J, Spiegelman D, Piton A, Lafreniere RG, Laurent S, St-Onge J, Lapointe L, Hamdan FF, Cossette P, Mottron L, et al: Novel de novo SHANK3 mutation in autistic patients. Am J Med Genet B Neuropsychiatr Genet 2009, 150B:421-424.

29. Gauthier J, Champagne N, Lafreniere RG, Xiong L, Spiegelman D, Brustein E, Lapointe $\mathrm{M}$, Peng $\mathrm{H}$, Cote $\mathrm{M}$, Noreau $\mathrm{A}$, et al: De novo mutations in the gene encoding the synaptic scaffolding protein SHANK3 in patients ascertained for schizophrenia. Proc Natl Acad Sci USA 2010, 107:7863-7868.

30. Berkel S, Marshall CR, Weiss B, Howe J, Roeth R, Moog U, Endris V, Roberts W, Szatmari P, Pinto D, et al: Mutations in the SHANK2 synaptic scaffolding gene in autism spectrum disorder and mental retardation. Nat Genet 2010, 42:489-491.

31. Pinto D, Pagnamenta AT, Klei L, Anney R, Merico D, Regan R, Conroy J, Magalhaes TR, Correia C, Abrahams BS, et al: Functional impact of global rare copy number variation in autism spectrum disorders. Nature 2010, 466:368-372.

32. Hughes ED, Qu YY, Genik SJ, Lyons RH, Pacheco CD, Lieberman AP, Samuelson LC, Nasonkin IO, Camper SA, Van Keuren ML, Saunders TL: Genetic variation in C57BL/6 ES cell lines and genetic instability in the Bruce4 C57BL/6 ES cell line. Mamm Genome 2007, 18:549-558.

33. Hellemans J, Mortier G, De Paepe A, Speleman F, Vandesompele J: qBase relative quantification framework and software for management and automated analysis of real-time quantitative PCR data. Genome Biol 2007, 8:R19.

34. Yang $Y$, Wang $X B$, Frerking $M$, Zhou Q: Spine expansion and stabilization associated with long-term potentiation. J Neurosci 2008, 28:5740-5751.

35. Bozdagi O, Wang XB, Nikitczuk JS, Anderson TR, Bloss EB, Radice GL, Zhou Q, Benson DL, Huntley GW: Persistence of coordinated long-term potentiation and dendritic spine enlargement at mature hippocampal CA1 synapses requires N-cadherin. J Neurosci 2010, 30:9984-9989.

36. Holtmaat AJ, Trachtenberg JT, Wilbrecht L, Shepherd GM, Zhang X, Knott GW, Svoboda K: Transient and persistent dendritic spines in the neocortex in vivo. Neuron 2005, 45:279-291.

37. Wearne SL, Rodriguez A, Ehlenberger DB, Rocher AB, Henderson SC, Hof PR: New techniques for imaging, digitization and analysis of threedimensional neural morphology on multiple scales. Neuroscience 2005 136:661-680

38. Rodriguez A, Ehlenberger DB, Dickstein DL, Hof PR, Wearne SL: Automated three-dimensional detection and shape classification of dendritic spines from fluorescence microscopy images. PLoS One 2008, 3:e1997.

39. Rodriguez A, Ehlenberger DB, Hof PR, Wearne SL: Rayburst sampling, an algorithm for automated three-dimensional shape analysis from laser scanning microscopy images. Nat Protoc 2006, 1:2152-2161.

40. Bozdagi O, Rich E, Tronel S, Sadahiro M, Patterson K, Shapiro ML, Alberini CM, Huntley GW, Salton SR: The neurotrophin-inducible gene Vgf regulates hippocampal function and behavior through a brain-derived neurotrophic factor-dependent mechanism. J Neurosci 2008 28:9857-9869.

41. Huber KM, Kayser MS, Bear MF: Role for rapid dendritic protein synthesis in hippocampal mGluR-dependent long-term depression. Science 2000, 288:1254-1257.

42. Dumutriu D, Hara Y, Berger S, Wadsworth S, Morrison J: Volume assisted measurement of puncta in 2 dimensions (VAMP2D): A new tool for accurate size quantification in fluorescent imaging. Society for Neurosience Annual Meeting Chicago, IL: Society for Neuroscience Abstracts; 2009.

43. Scattoni ML, Gandhy SU, Ricceri L, Crawley JN: Unusual repertoire of vocalizations in the BTBR T+tf/J mouse model of autism. PLOS One 2008, 3:e3067. 
44. Silverman JL, Turner SM, Barkan CL, Tolu SS, Saxena R, Hung AY, Sheng M, Crawley JN: Sociability and motor functions in Shank1 mutant mice. Brain Res 2010.

45. Scattoni ML, Ricceri L, Crawley JN: Unusual repertoire of vocalizations in adult BTBR $\mathrm{T}+\mathrm{tf} / \mathrm{J}$ mice during three types of social encounters. Genes Brain Behav 2010.

46. Yang M, Crawley JN: Simple behavioral assessment of mouse olfaction. Curr Protoc Neurosci 2009, Chapter 8(Unit 8):24.

47. Silverman JL, Yang M, Lord C, Crawley JN: Behavioural phenotyping assays for mouse models of autism. Nat Rev Neurosci 2010, 11:490-502.

48. Matsuzaki M, Honkura N, Ellis-Davies GC, Kasai H: Structural basis of longterm potentiation in single dendritic spines. Nature 2004, 429:761-766.

49. Kopec CD, Real E, Kessels HW, Malinow R: GluR1 links structural and functional plasticity at excitatory synapses. J Neurosci 2007, 27:13706-13718.

50. Nyby J: Ultrasonic vocalizations during sex behavior of male house mice (Mus musculus): a description. Behav Neural Biol 1983, 39:128-134.

51. Maunakea AK, Nagarajan RP, Bilenky M, Ballinger TJ, D'Souza C, Fouse SD, Johnson BE, Hong C, Nielsen C, Zhao Y, et al: Conserved role of intragenic DNA methylation in regulating alternative promoters. Nature 2010, 466:253-257.

52. Kolevzon A, Cai G, Soorya L, Takahashi N, Grodberg D, Kajiwara Y, Willner JP, Tryfon A, Buxbaum JD: Analysis of a purported SHANK3 mutation in a boy with autism: Clinical impact of rare variant research in neurodevelopmental disabilities. Brain Res 2010.

53. Uchino $S$, Wada H, Honda S, Nakamura Y, Ondo Y, Uchiyama T, Tsutsumi M, Suzuki E, Hirasawa T, Kohsaka S: Direct interaction of post-synaptic density-95/Dlg/ZO-1 domain-containing synaptic molecule Shank3 with GluR1 alpha-amino-3-hydroxy-5-methyl-4-isoxazole propionic acid receptor. J Neurochem 2006, 97:1203-1214.

54. Malinow R, Malenka RC: AMPA receptor trafficking and synaptic plasticity. Annu Rev Neurosci 2002, 25:103-126.

55. Shi S, Hayashi Y, Esteban JA, Malinow R: Subunit-specific rules governing AMPA receptor trafficking to synapses in hippocampal pyramidal neurons. Cell 2001, 105:331-343.

56. Park M, Penick EC, Edwards JG, Kauer JA, Ehlers MD: Recycling endosomes supply AMPA receptors for LTP. Science 2004, 305:1972-1975.

57. Ehrlich I, Malinow R: Postsynaptic density 95 controls AMPA receptor incorporation during long-term potentiation and experience-driven synaptic plasticity. J Neurosci 2004, 24:916-927.

58. El-Husseini AE, Schnell E, Chetkovich DM, Nicoll RA, Bredt DS: PSD-95 involvement in maturation of excitatory synapses. Science 2000, 290:1364-1368.

59. Stein V, House DR, Bredt DS, Nicoll RA: Postsynaptic density-95 mimics and occludes hippocampal long-term potentiation and enhances longterm depression. J Neurosci 2003, 23:5503-5506.

60. King BH, Bostic JQ: An update on pharmacologic treatments for autism spectrum disorders. Child Adolesc Psychiatr Clin N Am 2006, 15:161-175.

61. Bear MF, Huber KM, Warren ST: The mGluR theory of fragile $\mathbf{X}$ mental retardation. Trends Neurosci 2004, 27:370-377.

62. Ehninger D, Silva AJ: Genetics and neuropsychiatric disorders: treatment during adulthood. Nat Med 2009, 15:849-850.

63. Tropea D, Giacometti E, Wilson NR, Beard C, McCurry C, Fu DD, Flannery R, Jaenisch R, Sur M: Partial reversal of Rett Syndrome-like symptoms in MeCP2 mutant mice. Proc Natl Acad Sci USA 2009, 106:2029-2034.

64. Ehninger D, de Vries PJ, Silva AJ: From mTOR to cognition: molecular and cellular mechanisms of cognitive impairments in tuberous sclerosis. $J$ Intellect Disabil Res 2009, 53:838-851.

doi:10.1186/2040-2392-1-15

Cite this article as: Bozdagi et al:: Haploinsufficiency of the autismassociated Shank3 gene leads to deficits in synaptic function, social interaction, and social communication. Molecular Autism 2010 1:15.

\section{Submit your next manuscript to BioMed Central and take full advantage of:}

- Convenient online submission

- Thorough peer review

- No space constraints or color figure charges

- Immediate publication on acceptance

- Inclusion in PubMed, CAS, Scopus and Google Scholar

- Research which is freely available for redistribution

Submit your manuscript at www.biomedcentral.com/submit
Biomed Central 